\title{
FACTORS RELATED TO THE ALCOHOL USE AMONG STUDENTS ATTENDING YOUTH CORRECTIONAL CENTRES
}

\section{CZYNNIKI WARUNKUJĄCE PICIE ALKOHOLU WŚRÓD PODOPIECZNYCH MŁODZIEŻOWYCH OŚRODKÓW SOCJOTERAPEUTYCZNYCH I WYCHOWAWCZYCH}

\author{
Krzysztof Jan Bobrowski ID, Jakub Greń ID, Krzysztof Ostaszewski ID, Agnieszka Pisarska ID \\ Public Health Department, Youth Prevention Unit “Pro-M”, Institute of Psychiatry and Neurology, Warsaw, Poland
}

Zakład Zdrowia Publicznego, Pracownia Profilaktyki Młodzieżowej „Pro-M”, Instytut Psychiatrii i Neurologii, Warszawa, Polska

Alcohol Drug Addict 2019; 32 (4): 317-336

DOI: https://doi.org/10.5114/ain.2019.94025

\begin{abstract}
Introduction: We have extensive knowledge of the many factors related to young people's alcohol consumption in the general population. However, less is known about risk and protective factors among at-risk youth attending special education centres, i.e. youth sociotherapy centres (MOS) and youth correctional centres (MOW). The study aim was to identify the psychosocial and behavioural factors determining the frequency of drinking, alcohol abuse, or alcohol-related problems among adolescents at particular risk.

Material and methods: Data were collected from a random sample of 12-19-year-old students
\end{abstract}

\section{Streszczenie}

Wprowadzenie: Dotychczasowe badania pozwoliły zidentyfikować wiele czynników warunkujących picie alkoholu przez młodzież z populacji generalnej. Mniej natomiast wiadomo o czynnikach ryzyka i czynnikach chroniących młodzież szczególnie zagrożoną. W szczególności brakuje badań z udziałem młodzieży objętej edukacją specjalną w młodzieżowych ośrodkach socjoterapii (MOS) i młodzieżowych ośrodkach wychowawczych (MOW). Celem badań była identyfikacja psychospołecznych i behawioralnych czynników warunkujących częstość picia, nadużywanie alkoholu oraz problemy związane z piciem wśród młodzieży szczególnie zagrożonej.

Correspondence to/Adres do korespondencji: Krzysztof Jan Bobrowski, Zakład Zdrowia Publicznego, Pracownia Profilaktyki Młodzieżowej „Pro-M”, Instytut Psychiatrii i Neurologii, ul. Sobieskiego 9, 02-957 Warszawa, Polska, phone: +48 22 21 82 216, e-mail: kbob@ipin.edu.pl

Authors' contribution/Wkład pracy autorów: Study design/Koncepcja badania: K.J. Bobrowski, A. Pisarska, K. Ostaszewski; Data collection/Zebranie danych: A. Pisarska, J. Greń; Statistical analysis/Analiza statystyczna: K.J. Bobrowski; Data interpretation/Interpretacja danych: K.J. Bobrowski; Acceptance of final manuscript version/Akceptacja ostatecznej wersji pracy: K.J. Bobrowski, K. Ostaszewski; Literature search/Przygotowanie literatury: A. Pisarska, K. Ostaszewski, J. Greń, K.J. Bobrowski; Funds collection/Pozyskanie środków (finansowania): A. Pisarska, K. Ostaszewski.

No ghostwriting and guest authorship declared./Nie występują zjawiska ghostwriting i guest authorship.

Submitted/Otrzymano: 27.09.2019 • Accepted/Przyjęto do druku: 04.11.2019

(C) 2019 Institute of Psychiatry and Neurology. Production and hosting by Termedia sp. z o.o.

This is an open access article under the CC BY-NC-ND license (http://creativecommons.org/licenses/by-nc-nd/4.0/) 
of special education centres $(n=1730)$. The analysed factors concerned three areas: 1) individual, sociological and psychological characteristics, 2) social, peer and family influences, 3 ) free-time activities.

Results: The strongest determinant of alcohol consumption, getting drunk and alcohol-related problems were subjective norms conducive to substance use. Among individual factors, sensation seeking, experience of suicide attempt and in some models impulsiveness and low self-control were significant. The social environment also played a role among risk factors, i.e. positive relationships with peers, perceived use of psychoactive substances by close peers and alcohol problems among non-familial adults. On the other hand, parental monitoring of a teenager's free time proved to be a protective factor. Some leisure time activities had a limited role and were significant in the model explaining only the frequency of drinking.

Discussion: Particularly noteworthy is the relationship between the experience of suicide attempt and deeper involvement in drinking. It is surprising that there is no significant importance of parental support as a protective factor in excessive drinking.

Conclusions: Preventive actions addressed to students of special education centres should be focused on modifiable factors like subjective norms, self-control skills, attractive organised leisure time activities, prevention of suicide attempts and strengthening students' mental health.

Keywords: Alcohol use, Risk/protective factors, Youth at-risk, Youth correctional centres
Materiał i metody: Badania przeprowadzono na losowej próbie podopiecznych ośrodków w wieku $12-19$ lat $(n=1730)$. Analizowane czynniki dotyczyły trzech obszarów: 1) charakterystyki indywidualnej, socjologicznej i psychologicznej, 2) wpływów społecznych, rówieśniczych i rodzinnych, 3) aktywności w czasie wolnym.

Wyniki: Najsilniejszym czynnikiem warunkującym spożywanie alkoholu, upijanie się oraz problemy wynikające z picia były subiektywne normy sprzyjające używaniu substancji psychoaktywnych. Spośród czynników indywidualnych istotne znaczenie miało poszukiwanie wrażeń, przebyta próba samobójcza, a także w niektórych modelach - impulsywność i niska samokontrola. Znaczącą rolę wśród czynników ryzyka odgrywały również następujące aspekty środowiska społecznego: pozytywne relacje $z$ rówieśnikami, spostrzegane używanie alkoholu i innych substancji psychoaktywnych przez bliskich kolegów oraz rozpowszechnienie problemów alkoholowych wśród znajomych dorosłych. Natomiast monitorowanie przez rodziców czasu wolnego nastolatka okazało się czynnikiem chroniącym. Niektóre aspekty spędzania czasu wolnego miały ograniczone znaczenie i były istotne tylko w modelu wyjaśniającym częstość picia.

Omówienie: Na szczególną uwagę zasługuje związek pomiędzy doświadczeniem próby samobójczej a większym zaangażowaniem w picie alkoholu. Zaskakujący jest brak istotnego znaczenia wsparcia rodziców jako czynnika chroniącego przed nadmiernym piciem.

Wnioski: Działania profilaktyczne wśród podopiecznych ośrodków powinny być ukierunkowane na możliwe do modyfikacji czynniki: kształtowanie subiektywnych norm przeciwnych piciu alkoholu i używaniu innych substancji psychoaktywnych, rozwijanie umiejętności samokontroli, oferowanie młodzieży dopasowanych do ich potrzeb zorganizowanych zajęć w czasie wolnym, działania zapobiegające próbom samobójczym i wzmacniające zdrowie psychiczne podopiecznych MOS i MOW.

Słowa kluczowe: picie alkoholu, czynniki ryzyka/ chroniące, młodzież z grup ryzyka, ośrodki socjoterapeutyczne, ośrodki wychowawcze

\section{- INTRODUCTION}

A significant proportion of adolescents initiate drinking and experimenting with psychoactive substances. It is at this age that the patterns

\section{- WPROWADZENIE}

W okresie dojrzewania znacząca część młodzieży podejmuje pierwsze próby picia alkoholu, a także używania innych substancji psychoaktyw- 
of substance use in adulthood take shape. Alcohol consumption by young people may be the cause of serious disorders in the biological processes of their development and may hinder the overcoming of key challenges on the road to adulthood like the completion of education, employment or the establishment of stable, long-term interpersonal relations [1-3].

Studies on the determinants of young people's drinking patterns and alcohol-related problems have a long tradition and extensive literature especially in the USA [4-14]. This type of research has also been carried out here in Poland for many years [15-23]. It is known that many psychosocial factors can promote alcohol consumption among youth in general, but we know less about the risk and protective factors among youth at particular risk. We have a shortage of research on young people at national level, which includes special education at youth sociotherapy centres (MOS) and youth correctional centres (MOW). Studies in these types of centres in Poland are sometimes carried out, but tend to focus on other areas of concern, like for example, students' life in the centre or the process of resocialisation [24]. The possibilities of using research findings carried out in other countries are also limited, due to organisational differences in the special education system. For example, in the Dutch system, there are two separate types of schools equivalent to the Polish sociotherapy centres. One type is schools for students with learning disabilities, and the other is for young people with behavioural or emotional disorders. In addition, there are centres in the Netherlands very similar to our MOW, but the recruitment system is different. Furthermore, the Dutch court for juveniles has a supervisory role only while the decision to refer for temporary stay at an institution is taken by the agency responsible for childcare [25]. In our system, the decision belongs to a court for juveniles [24: 57].

In recent years, we have observed a decline in the prevalence of alcohol consumption among young people in Poland and many other countries. However, alcohol remains a psychoactive substance used by a significant proportion of youth [17, 26-28]. When we compare young people in the special education system to their peers attending regular schools, we find they are nych. Zaczynają kształtować się wzory używania substancji, jakie będą miały miejsce w wieku dorosłym. Spożywanie alkoholu przez młodych ludzi może być przyczyną poważnych zakłóceń biologicznych procesów rozwojowych i utrudniać realizację kluczowych zadań na drodze do dorosłości, takich jak zakończenie edukacji, podjęcie zatrudnienia czy nawiązywanie trwałych relacji interpersonalnych [1-3].

Badania nad determinantami wzorów picia alkoholu i problemami związanymi $\mathrm{z}$ alkoholem wśród młodych ludzi mają długą tradycję i bogate piśmiennictwo, przede wszystkim w USA [4-14]. Także w Polsce od wielu lat prowadzone są tego typu prace badawcze [15-23]. Wiadomo, że wiele czynników psychospołecznych może sprzyjać spożywaniu alkoholu przez młodych ludzi, jednak mniej wiemy o czynnikach ryzyka i ochronnych wśród szczególnie zagrożonej młodzieży. Z pewnością mamy niedostatek krajowych badań młodzieży, która jest objęta edukacją specjalną w młodzieżowych ośrodkach socjoterapii (MOS) i młodzieżowych ośrodkach wychowawczych (MOW). Badania w tego typu ośrodkach w Polsce są co prawda czasem prowadzone, ale koncentrują się na innych obszarach i dotyczą np. życia w ośrodku czy procesu resocjalizacji w placówkach [24]. Możliwości korzystania z prac badawczych prowadzonych $\mathrm{w}$ innych krajach są także ograniczone $\mathrm{z}$ powodu różnic organizacyjnych $\mathrm{w}$ systemie edukacji specjalnej. Na przykład w systemie holenderskim są dwa oddzielne typy szkół będące odpowiednikami polskich ośrodków socjoterapii. Jeden typ to szkoły dla uczniów z problemami w uczeniu się, a drugi - dla młodzieży z zaburzeniami zachowania lub emocjonalnymi. Ponadto w Holandii istnieją placówki bardzo podobne do naszych MOW, ale inny jest system kwalifikacji. Holenderski sąd dla nieletnich pełni jedynie funkcję kontrolną, natomiast decyzja o skierowaniu do placówki na okresowy pobyt jest podejmowana przez urząd ds. opieki nad dziećmi [25]. W naszym systemie decyzja należy do sądu dla nieletnich [24: 57].

W ostatnich latach obserwowano spadek rozpowszechnienia spożycia alkoholu wśród młodych ludzi w Polsce i wielu innych krajach. Niemniej alkohol pozostaje substancją psychoaktywną używaną przez znaczącą część młodych ludzi [17, 26-28]. Młodzież objęta systemem edukacji specjalnej, w porównaniu z rówieśnikami uczęszczającymi do szkół ogólnodostępnych, jest wyjątkowo 
extremely prone to frequently getting drunk, as well as to using of other psychoactive substances, which are much more widespread among the students of the special education system than in the general population of the corresponding age. This is demonstrated by the analyses carried out as part of this project and described in a separate article [29]. Similar regularities were also identified in British studies, which compared the prevalence of alcohol consumption and the use of other substances among special-education centre and "mainstream" education pupils [30].

The aim of the presented analyses was to identify sociodemographic, environmental and individual factors as well as free time activities determining the frequency of drinking and alcohol abuse and intensity of problems arising from drinking among MOS and MOW students.

\section{- MATERIAL AND METHODS}

We present below only the most important selected information on the method. The introductory article included more information on the study group, research tools and procedures as well as variable indicators [31].

\section{Study group}

A sample of 25 MOS and 39 MOW centres was randomly selected, making a total of 64 centres with 2585 pupils. Due to refusals by the management or other problems, several centres of a similar type were additionally selected. Completed questionnaires were obtained from $2063 \mathrm{MOS}$ and MOW pupils, which constituted $76 \%$ of the total number in the selected centres. Some questionnaires were discarded due to numerous questions without answer or entries suggesting a frivolous attitude towards the study. Finally, statistical analyses covered data obtained from 1730 respondents, of which 662 were MOS and 1068 from MOW pupils. The anonymous questionnaire was completed by individual students in their classrooms supervised by experienced, trained interviewers.

\section{Variables}

\section{Drinking alcohol}

Three scales characterising alcohol drinking were analysed: the frequency of drinking, the frequency of getting drunk and number of alco- narażona na częste upijanie się, a także używanie innych substancji psychoaktywnych, które wśród podopiecznych ośrodków są dużo bardziej rozpowszechnione niż w analogicznej wiekowo populacji ogólnej. Dowodzą tego analizy przeprowadzone $\mathrm{w}$ ramach niniejszego projektu i opisane $\mathrm{w}$ oddzielnym artykule [29]. Podobne prawidłowości zidentyfikowano także $\mathrm{w}$ badaniach brytyjskich, $\mathrm{w}$ których porównywano rozpowszechnienie picia alkoholu i używania innych substancji wśród rezydentów ośrodków edukacji specjalnej oraz uczniów z „głównego nurtu” edukacji [30].

Celem prezentowanych analiz było zidentyfikowanie czynników socjodemograficznych, środowiskowych oraz opisujących właściwości indywidualne, a także sposoby spędzania czasu wolnego warunkujących częstość picia i nadużywania alkoholu oraz nasilenie problemów wynikających z picia wśród podopiecznych MOS i MOW.

\section{- MAteriat I METOdy}

Szczegółowe informacje na temat badanej grupy, procedur i narzędzi badawczych oraz wskaźników zmiennych zamieszczono w artykule wprowadzającym [31]. Poniżej przedstawiono jedynie najważniejsze, wybrane informacje na ten temat.

\section{Badana grupa}

Losowo dobrano do badań 25 placówek MOS i 39 MOW, łącznie 64 ośrodki, w których uczyło się 2585 wychowanków. Z powodu odmowy dyrekcji lub innych problemów $\mathrm{z}$ udziałem $\mathrm{w}$ badaniach wylosowanych placówek dokonano celowego doboru kilku podobnego typu ośrodków. Wypełnione ankiety uzyskano od 2063 podopiecznych MOS i MOW, co stanowiło 76\% łącznej liczby uczniów w badanych placówkach. Ze względu na liczne braki danych lub dopiski sugerujące niepoważną postawę wobec badania część ankiet zdyskwalifikowano. Ostatecznie analizy statystyczne objęły dane uzyskane od 1730 respondentów - 662 podopiecznych MOS i 1068 z MOW. Anonimowy kwestionariusz był samodzielnie wypełniany przez uczniów w klasach, a badania prowadzili doświadczeni i przeszkoleni ankieterzy.

\section{Zmienne}

\section{Picie alkoholu}

Analizowano trzy skale charakteryzujące picie alkoholu: częstość picia alkoholu, częstość 
hol-related problems. Each of the first two scales was based on the answers to three component questions about the frequency of drinking or getting drunk throughout life, in the last year and in the last 30 days prior to the survey, with categories of answers assigned consecutive numbers from 1 ("I did not drink") to 7 ("40 times or more"). The scales were created by adding together answers to the component questions. The third scale added up the number of problems experienced as a result of drinking alcohol in the last year, like problems with the police, parents or financial problems.

\section{Protective and risk factors}

The variables included in the statistical analyses related to the following areas:

a) individual features: subjective norms conducive to psychoactive substance use, sensation seeking, impulsiveness, self-control, internalising problems (depression symptoms or other mental health problems) and experience of suicide attempt;

b) social environment: parental support, parental monitoring, conflicts in the family, alcohol problems among non-familial adult, the use of psychoactive substances by close peers, positive peer relationships and social climate at the centre;

c) sociodemographic variables (reference categories in parentheses): type of centre (MOS), length of stay in the centre (up to 1 year), gender (female), age group 16-19 years (12-15 years), repetition of the school year (maximum once), family composition (full), family financial situation (average or worse), religious commitment (small);

d) free-time activities (categorised by median): 1) weekly time spent in shopping malls, shops (less than 1 hour), organised sport activities (0 hours), organised non-sport activities (0 hours), individual physical activity (less than 1 hour); 2) daily activities: computer games (0 hours), listening to music (less than 3 hours), using the internet though not for educational purposes (less than 3 hours), doing homework (less than 1 hour), personal interest - hobby (less than 3 hours), reading for pleasure (0 hours). upijania się i problemy wynikające z picia. Dwie pierwsze skale powstały na podstawie odpowiedzi na trzy pytania składowe o częstość picia lub upijania się: w całym życiu, ostatnim roku i ostatnich 30 dniach przed badaniem, z kategoriami odpowiedzi, którym przypisano kolejne liczby od 1 („nie piłem”) do 7 („40 razy lub więcej"). Skale powstały poprzez zsumowanie odpowiedzi osób badanych na pytania składowe. Trzecia skala sumowała liczbę problemów doświadczanych w wyniku picia alkoholu $\mathrm{w}$ ostatnim roku, takich jak np. kłopoty z policją, $\mathrm{z}$ rodzicami, finansowe.

\section{Czynniki chroniące i czynniki ryzyka}

Zmienne uwzględnione w analizach statystycznych odnosiły się do następujących obszarów:

a) właściwości indywidualne: subiektywne normy dotyczące używania substancji psychoaktywnych, potrzeba wrażeń, impulsywność, samokontrola, problemy internalizacyjne (symptomy depresji lub inne problemy ze zdrowiem psychicznym), doświadczenie próby samobójczej;

b) środowisko społeczne: wsparcie rodziców, monitorowanie dziecka przez rodziców, konflikty $\mathrm{w}$ rodzinie, problemy alkoholowe wśród znajomych dorosłych, używanie substancji psychoaktywnych przez rówieśników, pozytywne relacje $\mathrm{z}$ rówieśnikami, klimat społeczny ośrodka;

c) zmienne socjodemograficzne (w nawiasach kategorie referencyjne): typ ośrodka (MOS), długość pobytu w ośrodku (do 1 roku), płeć (kobiety), grupa wiekowa 16-19 lat (12-15 lat), powtarzanie klasy (maksymalnie $1 \mathrm{raz}$ ), skład rodziny (pełna), sytuacja finansowa rodziny (przeciętna lub gorsza), zaangażowanie religijne (małe);

d) aktywności w czasie wolnym (podział na kategorie wg mediany): 1) w wymiarze tygodniowym: spędzanie czasu w centrach handlowych, sklepach (poniżej 1 godz.), zorganizowane zajęcia sportowe (0 godz.), zorganizowane zajęcia inne niż sportowe ( 0 godz.), indywidualna aktywność fizyczna (poniżej 1 godz.); 2) codzienne aktywności: gry komputerowe (0 godz.), słuchanie muzyki (poniżej 3 godz.), korzystanie $\mathrm{z}$ internetu, nie dotyczy nauki (poniżej 3 godz.), odrabianie lekcji (poniżej 1 godz.), osobiste zainteresowania - hobby (poniżej 3 godz.), czytanie dla przyjemności ( 0 godz.). 


\section{Statistical analysis}

The aim of the analysis was to define three models of relationships between variables that would explain the frequency of drinking alcohol, the getting drunk and the number of alcohol-related problems. Using the Kolmogorov-Smirnov test, we checked whether these three variables' distributions differ significantly from normal distributions. This fact was taken into account when selecting subsequent statistical tests. Thus Spearman rho was used in the correlation analyses and the Mann-Whitney $U$ test for intergroup differences. Only variables that significantly correlated $(p \leq 0.05)$ with a specific explained variable (e.g. with the frequency of drinking alcohol) were included in the final analyses. The Generalized Linear Model (GENLIN) with gamma distribution (SPSS 15.0 statistical package) was used, in which the variables were introduced into analysis in three blocks: 1 block - variables characterising the individual properties and the social environment; block 2 - sociodemographic variables were attached; block 3 - variables describing free-time activities were included. Hierarchical stepwise backward analysis was performed inside each block. This meant that during the block analysis cycle, all variables from a given block were first introduced into the analysis, and then subsequent variables with the lowest and insignificant Wald statistics values were removed step by step. Therefore what remained in the last step were the statistically significant variables improving the model fit.

Multivariate analyses required replacement of missing data, especially on scales consisting of numerous component questions. This process was carried out in two stages. The first stage assumes that data supplementation applies when the respondent answered most of the component questions of a given scale. The score on the scale was calculated by adding the numbers assigned to the answers to individual questions and dividing this sum by the number of answered questions. The remaining missing data for scales were supplemented by multiple imputation (MI - Multiple Imputation, statistical package SPSS 17.0).

\section{Analizy statystyczne}

Celem analiz było określenie trzech modeli zależności między zmiennymi, które wyjaśniałyby częstość picia alkoholu, częstość upijania się oraz liczbę problemów wynikających z picia alkoholu. Korzystając z testu Kołmogorowa-Smirnowa, wykazano, że rozkłady tych trzech zmiennych znacząco odbiegają od rozkładów normalnych. Fakt ten uwzględniono przy wyborze stosowanych dalej testów statystycznych. W analizach korelacyjnych stosowano rho Spearmana, a w przypadku różnic międzygrupowych wykorzystano test $U$ MannaWhitneya. Do finalnych analiz włączano tylko te zmienne, które istotnie korelowały $(p \leq 0,05)$ z określoną zmienną wyjaśnianą (np. z częstością picia alkoholu). Wykorzystano uogólniony model liniowy (Generalized Linear Model - GENLIN) $\mathrm{z}$ rozkładem gamma (pakiet statystyczny SPSS 15.0), w którym zmienne wprowadzano do analiz w trzech blokach: 1 - zmienne charakteryzujące właściwości indywidualne jednostki i otoczenie społeczne; 2 - dołączano zmienne socjodemograficzne; 3 - dołączano zmienne charakteryzujące aktywności w czasie wolnym. Wewnątrz każdego bloku prowadzono hierarchiczne analizy krokowe wstecz. Oznaczało to, że w trakcie cyklu analiz blokowych najpierw wprowadzano do analizy wszystkie zmienne $\mathrm{z}$ danego bloku, a następnie usuwano $\mathrm{z}$ modelu, krok po kroku, kolejne zmienne $\mathrm{z}$ najniższymi wewnątrz bloku i nieistotnymi wartościami statystyki Walda. Pozostawały natomiast zmienne poprawiające dopasowanie modelu, istotne statystycznie w ostatnim kroku.

Analizy wielozmiennowe wymagały uzupełnienia brakujących danych, szczególnie w skalach składających się z wielu pytań składowych. Przeprowadzono ten proces $\mathrm{w}$ dwu etapach. W pierwszym założono, że uzupełnienie danych dotyczyć będzie sytuacji, kiedy badany odpowiedział na większość pytań składowych danej skali. Wynik punktowy na skali liczono, sumując liczby przyporządkowane odpowiedziom na poszczególne pytania i dzieląc tę sumę przez liczbę pytań, na które uzyskano odpowiedzi. Pozostałe braki danych dla skal uzupełniano metodą wielokrotnej imputacji (MI - multiple imputation, pakiet statystyczny SPSS 17.0). 


\section{- RESULTS}

Correlations of continuous independent variables with dependent variables describing drinking

The first group of variables analysed, which potentially conditioning drinking, contained continuous variables describing the family and peer environment as well as individual properties. The correlation (Spearman rho) analyses showed that only one variable, the social climate at the centre, was not significantly related to the variables describing alcohol consumption (Table I). This variable was excluded from further analysis. Other variables significantly correlated with the frequency of drinking, getting drunk and number of alcohol-related problems. At the same time, as expected, negative correlations were found in the case of noticed parental support, perceived parental monitoring and subject's self-control. Other variables had posi-

\section{WYNIKI}

Korelacje zmiennych niezależnych ciągłych ze zmiennymi zależnymi opisującymi picie alkoholu

Pierwsza grupa analizowanych zmiennych, potencjalnie warunkujących picie alkoholu, zawierała zmienne ciągłe opisujące środowisko rodzinne i rówieśnicze oraz właściwości indywidualne. Przeprowadzone analizy korelacyjne (rho Spearmana) wykazały, że tylko jedna zmienna, „klimat ośrodka”, nie miała istotnego związku ze zmiennymi opisującymi picie alkoholu (tab. I). Zmienna ta została wykluczona $\mathrm{z}$ dalszych analiz. Pozostałe zmienne istotnie korelowały z częstością picia alkoholu, upijania się i nasileniem problemów wynikających z picia. Przy tym, zgodnie $\mathrm{z}$ oczekiwaniami, ujemne korelacje stwierdzono w przypadku odczuwanego wsparcia rodziców, postrzeganego monitorowania przez rodziców oraz samokontroli badanych uczniów. Pozostałe zmienne miały dodatnie korelacje $\mathrm{z}$ często-

Table I. Spearman's rho correlations between quantitative explanatory variables and alcohol drinking Tabela I. Korelacje rho Spearmana pomiędzy zmiennymi ilościowymi wyjaśniającymi i piciem alkoholu

\begin{tabular}{|c|c|c|c|}
\hline & $\begin{array}{l}\text { Alcohol use frequency } \\
\text { Częstość picia } \\
\text { alkoholu }\end{array}$ & $\begin{array}{l}\text { Frequency of getting } \\
\text { drunk } \\
\text { Częstość upijania się }\end{array}$ & $\begin{array}{c}\text { Alcohol-related problems } \\
\text { Problemy związane } \\
\text { z piciem }\end{array}$ \\
\hline $\begin{array}{l}\text { Parental support } \\
\text { Wsparcie rodziców }\end{array}$ & $-0.082^{\star \star}$ & $-0.072^{\star *}$ & $-0.086^{\star *}$ \\
\hline $\begin{array}{l}\text { Parental monitoring } \\
\text { Monitorowanie dziecka przez rodziców }\end{array}$ & $-0.155^{\star \star}$ & $-0.154^{\star *}$ & $-0.156^{\star \star}$ \\
\hline $\begin{array}{l}\text { Conflicts and domestic violence } \\
\text { Konflikty i przemoc w rodzinie }\end{array}$ & $0.182^{\star \star}$ & $0.209^{\star \star}$ & $0.219^{\star \star}$ \\
\hline $\begin{array}{l}\text { Positive relationships with peers } \\
\text { Pozytywne relacje } \mathrm{w} \text { rówieśnikami }\end{array}$ & $0.157^{\star *}$ & $0.128^{\star *}$ & $0.090^{\star *}$ \\
\hline $\begin{array}{l}\text { Psychoactive substance use among peers } \\
\text { Używanie substancji psychoaktywnych } \\
\text { wśród kolegów }\end{array}$ & $0.388^{* *}$ & $0.433^{\star *}$ & $0.409^{* *}$ \\
\hline $\begin{array}{l}\text { Alcohol problems among non-familial adults } \\
\text { Problemy alkoholowe wśród znajomych } \\
\text { dorosłych }\end{array}$ & $0.374^{\star *}$ & $0.423^{* *}$ & $0.373^{\star *}$ \\
\hline $\begin{array}{l}\text { Impulsiveness } \\
\text { Impulsywność }\end{array}$ & $0.200^{* *}$ & $0.167^{\star *}$ & $0.206^{\star *}$ \\
\hline $\begin{array}{l}\text { Sensation seeking } \\
\text { Poszukiwanie wrażeń }\end{array}$ & $0.381^{\star \star}$ & $0.385^{\star \star}$ & $0.376^{\star \star}$ \\
\hline $\begin{array}{l}\text { Self-control } \\
\text { Samokontrola }\end{array}$ & $-0.099^{\star \star}$ & $-0.093^{\star *}$ & $-0.146^{\star \star}$ \\
\hline $\begin{array}{l}\text { Subjective norms conducive to substance use } \\
\text { Subiektywne normy sprzyjające używaniu }\end{array}$ & $0.506^{\star *}$ & $0.512^{\star *}$ & $0.386^{\star *}$ \\
\hline $\begin{array}{l}\text { Social climate at the MOS/MOW } \\
\text { Klimat społeczny MOS/MOW }\end{array}$ & 0.013 & -0.002 & -0.006 \\
\hline
\end{tabular}

${ }^{* *} p<0.01$ 
tive correlations with the frequency of drinking, getting drunk and number of alcohol-related problems.

The highest correlations were found in the case of subjective norms, sensation seeking, perceived use of psychoactive substances by close peers and alcohol-related problems among non-familial adults. Other correlations were weaker but all remained at the significant level $p<0.01$.

\section{Dichotomous, sociodemographic and individual variables associated with scales describing drinking}

There were actually four dichotomous variables associated with all scales describing drinking alcohol: centre type, age group, internalizing problems and any history of attempted suicide (Table II). MOW pupils, older pupils, students, with a history of attempted suicide and those experiencing internalizing problems were characterised by higher scores on the drinking, getting drunk and alcohol-related problem scales.

Four more dichotomous factors were associated with the alcohol drinking scale: gender, school year repetition, family financial situation and religious commitment. Two additional factors were significantly related to the frequency of getting drunk (school year repetition and religious commitment). Also, two additional factors were significant for the number of alcohol-related problems (gender and family structure).

Length of stay in the centre up to one year vs. over a year, was not significant for the value of any of the three scales describing drinking. This variable was excluded from further analysis.

\section{Free-time activities and drinking}

The three variables describing drinking alcohol that were significantly and positively associated were listening to music and using the internet for 3 or more hours a day (this did not apply to educational purposes), devoting only a small amount of time to homework (less than 1 hour everyday) and spending time in shopping malls and stores (at least 1 hour per week).

The frequency of drinking was lower in groups of people who played computer games on a daily basis, read for pleasure every day and among participants of organised activities (except sports, at least once a week). ścią picia i upijania się oraz z nasileniem problemów wynikających z picia alkoholu.

Najwyższe korelacje stwierdzono w przypadku subiektywnych norm, zapotrzebowania na stymulację, spostrzeganego używania substancji psychoaktywnych przez bliskich kolegów i problemów alkoholowych wśród znajomych dorosłych spoza rodziny. Inne korelacje były słabsze, ale wszystkie utrzymywały się na poziomie istotności $p<0,01$.

\section{Związki zmiennych dychotomicznych, socjodemograficznych i indywidualnych ze skalami opisującymi picie alkoholu}

Ze wszystkimi skalami opisującymi picie alkoholu istotnie związane były cztery dychotomiczne zmienne: typ ośrodka, grupa wiekowa, problemy internalizacyjne (emocjonalne) i próby samobójcze (tab. II), przy czym rezydenci MOW, uczniowie starsi, uczniowie po przebytej próbie samobójczej oraz aktualnie doświadczający problemów charakteryzowali się wyższymi wynikami na skalach częstości picia alkoholu i upijania się oraz mieli więcej problemów związanych z piciem alkoholu.

Ze skalą częstości picia alkoholu były związane jeszcze cztery dychotomiczne czynniki: płeć, powtarzanie klasy, sytuacja finansowa rodziny oraz zaangażowanie religijne. Dwa dodatkowe czynniki były istotnie związane ze skalą częstości upijania się (powtarzanie klasy i zaangażowanie religijne). Również dwa dodatkowe czynniki były istotne dla liczby problemów wynikających z picia alkoholu (płeć i struktura rodziny).

Długość pobytu w ośrodku, do jednego roku $v s$ ponad rok, nie miał istotnego znaczenia dla poziomu wartości jakiejkolwiek spośród trzech skal opisujących picie alkoholu. Zmienna ta została wykluczona $\mathrm{z}$ dalszych analiz.

\section{Sposoby spędzania czasu wolnego a picie alkoholu}

Z trzema zmiennymi opisującymi picie alkoholu istotnie i dodatnio związane były: słuchanie muzyki oraz korzystanie $\mathrm{z}$ internetu przez 3 i więcej godzin dziennie (nie dotyczyło to celów edukacyjnych), poświęcanie małej ilości czasu na odrabianie lekcji (codzienne poniżej 1 godz.) oraz spędzanie czasu w centrach handlowych i sklepach (co najmniej 1 godz. tygodniowo).

Częstość picia alkoholu była mniejsza w grupach osób zajmujących się na co dzień grami komputerowymi, czytających codziennie dla przyjemności oraz wśród uczestników zorganizowanych zajęć (z wyjątkiem sportowych, co najmniej raz na tydzień). 
Table II. Binary variables and alcohol drinking

Tabela II. Zmienne dychotomiczne a picie alkoholu

\begin{tabular}{|c|c|c|c|c|c|c|}
\hline & \multicolumn{2}{|c|}{$\begin{array}{l}\text { Alcohol use frequency } \\
\text { Częstość picia alkoholu }\end{array}$} & \multicolumn{2}{|c|}{$\begin{array}{c}\text { Frequency of getting } \\
\text { drunk } \\
\text { Częstość upijania się }\end{array}$} & \multicolumn{2}{|c|}{$\begin{array}{c}\text { Alcohol-related problems } \\
\text { Problemy związane } \\
\text { z piciem }\end{array}$} \\
\hline & $\begin{array}{l}\text { Average } \\
\text { Średnia }\end{array}$ & $\begin{array}{c}\text { U Mann- } \\
\text { Whitney Sig. }\end{array}$ & $\begin{array}{l}\text { Average } \\
\text { Średnia }\end{array}$ & $\begin{array}{c}\text { U Mann- } \\
\text { Whitney Sig. }\end{array}$ & $\begin{array}{l}\text { Average } \\
\text { Średnia }\end{array}$ & $\begin{array}{c}\text { U Mann- } \\
\text { Whitney Sig. }\end{array}$ \\
\hline \multicolumn{7}{|l|}{ Type of centre/Typ ośrodka } \\
\hline MOS & 3.9235 & \multirow{2}{*}{0.000} & 2.8531 & \multirow{2}{*}{0.000} & 2.1992 & \multirow{2}{*}{0.000} \\
\hline MOW & 4.4185 & & 3.4492 & & 2.8969 & \\
\hline \multicolumn{7}{|l|}{ Gender/Płeć } \\
\hline Boys/Chłopcy & 4.1714 & \multirow{2}{*}{0.036} & 3.2300 & \multirow{2}{*}{ ns } & 2.4612 & \multirow{2}{*}{0.000} \\
\hline Girls/Dziewczęta & 4.3509 & & 3.2029 & & 2.9866 & \\
\hline \multicolumn{7}{|l|}{ Age group/Grupa wiekowa } \\
\hline $12-15$ & 3.8522 & \multirow{2}{*}{0.000} & 2.9356 & \multirow{2}{*}{0.000} & 2.3966 & \multirow{2}{*}{0.001} \\
\hline $16-19$ & 4.4739 & & 3.4060 & & 2.7832 & \\
\hline \multicolumn{7}{|l|}{ School year repetition/Powtarzanie klasy } \\
\hline At most once/Co najwyżej raz & 4.1411 & \multirow{2}{*}{0.004} & 3.1130 & \multirow{2}{*}{0.000} & 2.5902 & \multirow{2}{*}{ ns } \\
\hline Other answers/Inne odpowiedzi & 4.3926 & & 3.4221 & & 2.7044 & \\
\hline \multicolumn{7}{|c|}{ Length of stay in the centre/Długość pobytu w ośrodku } \\
\hline Up to one year/Do 1 roku & 4.2223 & \multirow{2}{*}{ ns } & 3.1885 & \multirow{2}{*}{ ns } & 2.7460 & \multirow{2}{*}{ ns } \\
\hline Other answers/Inne odpowiedzi & 4.2356 & & 3.2524 & & 2.5187 & \\
\hline \multicolumn{7}{|l|}{ Family composition/Struktura rodziny } \\
\hline Two parents/Dwoje rodziców & 4.1258 & \multirow{2}{*}{ ns } & 3.2394 & \multirow{2}{*}{ ns } & 2.4771 & \multirow{2}{*}{0.043} \\
\hline Other answers/Inne odpowiedzi & 4.2794 & & 3.2122 & & 2.7046 & \\
\hline \multicolumn{7}{|c|}{ Family financial situation/Sytuacja finansowa rodziny } \\
\hline Above average/Powyżej przeciętnej & 4.3157 & \multirow{2}{*}{0.024} & 3.3388 & \multirow{2}{*}{ ns } & 2.6791 & $n c$ \\
\hline Other answers/Inne odpowiedzi & 4.1796 & & 3.1539 & & 2.6022 & 110 \\
\hline Religious commitment/Zaangażowanie & eligijne & & & & & \\
\hline Low/Niskie & 4.3929 & חمחת & 3.3247 & 1 & 2.7034 & nc \\
\hline High/Wysokie & 3.9400 & 0.000 & 3.0383 & 0.001 & 2.5010 & 115 \\
\hline Internalizing problems/Problemy intern & lizacyjne & & & & & \\
\hline $\mathrm{No} / \mathrm{Nie}$ & 4.1167 & חمחת & 3.1656 & 0033 & 2.4308 & ח ח \\
\hline Yes/Tak & 4.4657 & & 3.3380 & & 3.0508 & 0.000 \\
\hline Suicide attempts/Próby samobójcze & & & & & & \\
\hline No/Nie & 4.0264 & חמת מ & 3.0561 & חמחת & 2.2429 & ח 0 \\
\hline Yes/Tak & 4.5293 & 0.000 & 3.4656 & 0.000 & 3.2035 & 0.000 \\
\hline
\end{tabular}

ns - non-significant/nieistotny

The frequency of getting drunk was also lower among those reading for pleasure and regularly participating in organised activities, and also among those devoting their free time to hobby (Table III). Realisation of personal interests was also conducive to reducing problems resulting from drinking. Similarly, individual physical activity was conducive to reducing
Częstość upijania się była także mniejsza wśród osób czytających dla przyjemności i uczestniczących regularnie $\mathrm{w}$ zorganizowanych zajęciach, ale również wśród uczestników badań poświęcających czas wolny na osobiste zainteresowania (tab. III). Realizacja osobistych zainteresowań sprzyjała też ograniczeniu problemów wynikających z picia. Analogicznie ograniczeniu problemów wyni- 
Table III. Free-time activities and alcohol drinking

Tabela III. Spędzanie czasu wolnego a skale opisujące picie alkoholu

\begin{tabular}{|c|c|c|c|c|c|c|}
\hline \multirow{2}{*}{$\begin{array}{l}\text { Free-time activities } \\
\text { Spędzanie wolnego czasu }\end{array}$} & \multicolumn{2}{|c|}{$\begin{array}{l}\text { Alcohol use frequency } \\
\text { Częstość picia alkoholu }\end{array}$} & \multicolumn{2}{|c|}{$\begin{array}{c}\text { Frequency of getting } \\
\text { drunk } \\
\text { Częstość upijania się }\end{array}$} & \multicolumn{2}{|c|}{$\begin{array}{c}\text { Alcohol-related problems } \\
\text { Problemy związane } \\
\text { z piciem }\end{array}$} \\
\hline & $\begin{array}{l}\text { Average } \\
\text { Średnia }\end{array}$ & $\begin{array}{c}\text { U Mann- } \\
\text { Whitney Sig. }\end{array}$ & $\begin{array}{l}\text { Average } \\
\text { Średnia }\end{array}$ & $\begin{array}{c}\text { U Mann- } \\
\text { Whitney Sig. }\end{array}$ & $\begin{array}{l}\text { Average } \\
\text { Średnia }\end{array}$ & $\begin{array}{c}\text { U Mann- } \\
\text { Whitney Sig. }\end{array}$ \\
\hline \multicolumn{7}{|c|}{ Free time every day/Czas wolny na co dzień } \\
\hline \multicolumn{7}{|l|}{ Computer games/Gry komputerowe } \\
\hline $\mathrm{No} / \mathrm{Nie}$ & 4.3746 & \multirow{2}{*}{0.003} & 3.3015 & \multirow{2}{*}{ ns } & 2.7627 & \multirow{2}{*}{ ns } \\
\hline Yes/Tak & 4.1145 & & 3.1579 & & 2.5257 & \\
\hline \multicolumn{7}{|l|}{ Listening to music/Słuchanie muzyki } \\
\hline Less than 3 h/Poniżej 3 godz. & 3.9493 & \multirow{2}{*}{0.000} & 3.0051 & \multirow{2}{*}{0.000} & 2.3895 & \multirow{2}{*}{0.000} \\
\hline More/Więcej & 4.5037 & & 3.4331 & & 2.8666 & \\
\hline \multicolumn{7}{|c|}{ Internet (not related to learning)/Internet (nie dotyczy nauki) } \\
\hline Less than $3 \mathrm{~h} /$ Poniżej 3 godz. & 4.0694 & \multirow{2}{*}{0.000} & 3.1304 & \multirow{2}{*}{0.015} & 2.4252 & \multirow{2}{*}{0.000} \\
\hline More/Więcej & 4.4406 & & 3.3413 & & 2.9021 & \\
\hline \multicolumn{7}{|l|}{ Homework/Odrabianie lekcji } \\
\hline Less than $1 \mathrm{~h} /$ Poniżej 1 godz. & 4.3570 & \multirow{2}{*}{0.000} & 3.3596 & \multirow{2}{*}{0.000} & 2.7315 & \multirow{2}{*}{0.039} \\
\hline More/Więcej & 4.0474 & & 3.0246 & & 2.4865 & \\
\hline \multicolumn{7}{|l|}{ Hobby/Osobiste zainteresowania } \\
\hline Less than $3 \mathrm{~h} /$ Poniżej 3 godz. & 4.2752 & \multirow{2}{*}{ ns } & 3.2804 & \multirow{2}{*}{0.022} & 2.7339 & \multirow{2}{*}{0.009} \\
\hline More/Więcej & 4.1421 & & 3.1094 & & 2.4344 & \\
\hline \multicolumn{7}{|c|}{ Reading books for pleasure/Czytanie dla przyjemności } \\
\hline No/Nie & 4.3246 & \multirow{2}{*}{0.006} & 3.3341 & \multirow{2}{*}{0.026} & 2.6633 & \multirow{2}{*}{ ns } \\
\hline Yes/Tak & 4.1535 & & 3.1318 & & 2.6039 & \\
\hline & ree time ir & typical week/ & zas wolny & tygodniu & & \\
\hline Shopping/Centra handlowe, sklep & & & & & & \\
\hline Less than $1 \mathrm{~h} /$ Poniżej 1 godz. & 4.1128 & مחת & 3.1450 & 010 & 2.5190 & م1000 \\
\hline More/Więcej & 4.4002 & 0.000 & 3.3330 & 0.018 & 2.7939 & 0.010 \\
\hline Organised sport/Sport zorganizov & any & & & & & \\
\hline No/Nie & 4.2221 & $n$ & 3.1549 & $n c$ & 2.5008 & 0010 \\
\hline Yes/Tak & 4.2361 & 115 & 3.2886 & 115 & 2.7620 & 0.014 \\
\hline Organised non-sport activities/Zo & yanizowan & zajęcia inne niż & portowe & & & \\
\hline No/Nie & 4.3649 & חמחמ & 3.3268 & ח חמת & 2.7098 & $n$ \\
\hline Yes/Tak & 4.0793 & 0.000 & 3.1047 & 0.006 & 2.5422 & nis \\
\hline Individual sport activity/Indywidu & Ina aktywr & ść fizyczna & & & & \\
\hline Less than $1 \mathrm{~h} /$ Poniżej 1 godz. & 4.2581 & & 3.2895 & & 2.7727 & 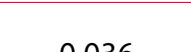 \\
\hline More/Więcej & 4.2050 & 115 & 3.1645 & TIS & 2.5118 & 0.030 \\
\hline
\end{tabular}

ns-non-significant/nieistotne

problems resulting from drinking, as long as it took place every day for at least one hour. Interestingly, people who regularly participated in organised sports activities had more intense problems. kających z picia alkoholu sprzyjała indywidualna aktywność fizyczna, jeśli tylko była uprawiana codziennie przez co najmniej jedną godzinę. Co ciekawe, większe nasilenie problemów charakteryzowało wychowanków, którzy regularnie uczestniczyli w zorganizowanych zajęciach sportowych. 


\section{Regression analysis}

Hierarchical (block-step) analyses with backward elimination of variables (generalised linear models - GENLIN with gamma distribution) resulted in three models of associations between variables explaining various aspects of drinking, which included the drinking frequency, the frequency of getting drunk and the intensity of alcohol-related problems. All variables in the final step in each model were statistically significant, so each variable included in the model significantly improved its parameters.

The three models obtained were quite similar because the same pool of eight significant factors was present in each (Table IV). These social factors were: parental monitoring (as a protective factor), positive relationships with peers, perceived use of the substance by close peers and alcohol problems among non-familial adults (as risk factors), and three individual factors, which were: subjective norms allowing the use of psychoactive substances, sensation seeking and a history of attempted suicide. Further factors are centre type and age. MOW pupils were more at risk of frequent drinking to their MOS peers, as they were of getting drunk and experiencing more alcohol-related problems.

Similarly, older students were at greater risk of frequent drinking and experiencing more alcohol-related problems. In the case of the model explaining frequent drunkenness, school year repetition rather than student's age were found to be significant. Students who repeated their school year at least twice, more often got drunk compared to other classmates.

Impulsiveness conducive to frequent drinking of alcohol and self-control that reduced the number of alcohol-related problems were the two other significant variables.

The most variables were found in the model explaining the frequency of drinking. Only in this model was there a group of three dichotomous variables describing different types of free-time activities. Daily listening to music (3 or more hours) was associated with frequent alcohol use, while games and regular, weekly participation in organised (non-sport) activities was associated with less frequent alcohol use.

It is worth noting, based on comparisons of Wald's statistics, that the strongest factor determining

\section{Analizy regresji}

Hierarchiczne analizy (blokowo-krokowe) z eliminacją wsteczną zmiennych (uogólnione modele liniowe GENLIN z rozkładem gamma) dały $\mathrm{w}$ efekcie trzy modele zależności między zmiennymi, wyjaśniające różne aspekty picia alkoholu: częstość picia alkoholu, częstość upijania się i nasilenie problemów wynikających $\mathrm{z}$ picia. Wszystkie zmienne, które znalazły się w końcowym kroku, w każdym modelu były istotne statystycznie, a więc każda zmienna włączona do modelu poprawiała istotnie jego parametry.

Uzyskane trzy modele były dość podobne, ponieważ ta sama pula ośmiu istotnych czynników powtarzała się w każdym z nich (tab. IV). Były to cztery czynniki społeczne, tj. monitorowanie dziecka przez rodziców (jako czynnik chroniący), dobre relacje $\mathrm{z}$ rówieśnikami, spostrzegane używanie substancji przez bliskich kolegów i problemy alkoholowe wśród znajomych dorosłych spoza rodziny (jako czynniki ryzyka), oraz trzy czynniki indywidualne, tj. subiektywne normy przyzwalające na używanie substancji psychoaktywnych, poszukiwanie wrażeń i przebyte próby samobójcze. Kolejne czynniki to typ ośrodka i wiek. Podopieczni MOW, w porównaniu z podopiecznymi MOS, byli bardziej zagrożeni częstym piciem alkoholu i upijaniem się oraz doświadczali większej liczby problemów z powodu picia.

Podobnie starsi uczniowie byli obarczeni większym ryzykiem częstego picia alkoholu i doświadczania większej liczby problemów z powodu picia alkoholu. W przypadku modelu wyjaśniającego częste upijanie się, zamiast wieku uczniów istotne okazało się powtarzanie klasy. Uczniowie, którzy powtarzali klasę co najmniej dwa razy, częściej upijali się $\mathrm{w}$ porównaniu $\mathrm{z}$ pozostałymi kolegami.

Istotne znaczenie miały jeszcze dwie zmienne indywidualne: impulsywność sprzyjała częstemu piciu alkoholu, a samokontrola - ograniczeniu liczby problemów wynikających z picia.

Najwięcej zmiennych znalazło się w modelu wyjaśniającym częstość picia alkoholu. Tylko w tym modelu znalazła się bowiem grupa trzech dychotomicznych zmiennych, opisujących różne sposoby spędzania czasu wolnego. Codzienne słuchanie muzyki ( 3 i więcej godzin) było związane $\mathrm{z}$ częstym sięganiem po alkohol, natomiast zajmowanie się na co dzień grami oraz regularne, cotygodniowe uczestniczenie w zorganizowanych zajęciach (innych niż sportowe) wiązało się z rzadszym sięganiem po alkohol.

Warto zauważyć, na podstawie porównań wartości statystyki Walda, że najsilniejszym czynnikiem 
Table IV. The last step in hierarchical regression analyzes (GENLIN, gamma distribution) with backward elimination of variables irrelevant to the model (Wald); explained variables: frequency of alcohol use, frequency of getting drunk and number of alcohol-related problems; $n=1721$

Tabela IV. Ostatni krok w hierarchicznych analizach regresji (GENLIN, rozkład gamma) z eliminacją wsteczną zmiennych nieistotnych dla modelu (Wald), zmienne wyjaśniane: częstość picia alkoholu, częstość upijania się i liczba problemów związanych z piciem alkoholu; $n=1721$

\begin{tabular}{|c|c|c|c|c|c|c|c|c|c|}
\hline \multirow[t]{2}{*}{ Factors/Czynniki } & \multicolumn{3}{|c|}{$\begin{array}{c}\text { Alcohol use frequency } \\
\text { Częstość } \\
\text { picia alkoholu }\end{array}$} & \multicolumn{3}{|c|}{$\begin{array}{l}\text { Frequency of getting } \\
\text { drunk } \\
\text { Częstość upijania się }\end{array}$} & \multicolumn{3}{|c|}{$\begin{array}{l}\text { Alcohol-related } \\
\text { problems } \\
\text { Problemy związane } \\
\text { z piciem }\end{array}$} \\
\hline & $B$ & Wald & $p$ & $B$ & Wald & $p$ & $B$ & Wald & $p$ \\
\hline \multicolumn{10}{|l|}{ Social factors/Czynniki społeczne } \\
\hline $\begin{array}{l}\text { Psychoactive substance use among } \\
\text { peers/Używanie substancji psycho- } \\
\text { aktywnych wśród koleżanek/kolegów }\end{array}$ & 0.219 & 19.11 & 0.000 & 0.287 & 44.95 & 0.000 & 0.464 & 44.79 & 0.000 \\
\hline $\begin{array}{l}\text { Positive relationships with peers } \\
\text { Pozytywne relacje z rówieśnikami }\end{array}$ & 0.339 & 51.10 & 0.000 & 0.184 & 23.45 & 0.000 & 0.144 & 7.08 & 0.008 \\
\hline $\begin{array}{l}\text { Parental monitoring } \\
\text { Monitorowanie przez rodziców }\end{array}$ & -0.144 & 18.25 & 0.000 & -0.074 & 7.39 & 0.007 & -0.106 & 6.86 & 0.009 \\
\hline $\begin{array}{l}\text { Alcohol problems among non- } \\
\text { familial adults } \\
\text { Problemy alkoholowe wśród } \\
\text { znajomych dorosłych }\end{array}$ & 0.258 & 23.85 & 0.000 & 0.313 & 46.30 & 0.000 & 0.356 & 25.79 & 0.000 \\
\hline \multicolumn{10}{|l|}{ Individual factors/Czynniki indywidualne } \\
\hline $\begin{array}{l}\text { Suicide attempts - Yes (no) } \\
\text { Próby samobójcze - Tak (nie) }\end{array}$ & 0.328 & 18.03 & 0.000 & 0.198 & 10.49 & 0.001 & 0.636 & 40.32 & 0.000 \\
\hline $\begin{array}{l}\text { Subjective norms conducive to } \\
\text { substance use } \\
\text { Subiektywne normy sprzyjające } \\
\text { używaniu substancji psych. }\end{array}$ & 0.477 & 188.6 & 0.000 & 0.432 & 224.3 & 0.000 & 0.285 & 42.17 & 0.000 \\
\hline $\begin{array}{l}\text { Sensation seeking } \\
\text { Poszukiwanie wrażeń }\end{array}$ & 0.248 & 48.73 & 0.000 & 0.190 & 40.39 & 0.000 & 0.343 & 52.30 & 0.000 \\
\hline $\begin{array}{l}\text { Impulsiveness } \\
\text { Impulsywność }\end{array}$ & 0.110 & 4.010 & 0.045 & & & & & & \\
\hline $\begin{array}{l}\text { Self-control } \\
\text { Samokontrola }\end{array}$ & & & & & & & -0.210 & 11.39 & 0.001 \\
\hline \multicolumn{10}{|c|}{ Sociodemographic factors/Czynniki socjodemograficzne } \\
\hline $\begin{array}{l}\text { Type of centre } \\
\text { Typ ośrodka (MOW, MOS) }\end{array}$ & 0.279 & 15.97 & 0.000 & 0.326 & 33.80 & 0.000 & 0.362 & 18.40 & 0.000 \\
\hline $\begin{array}{l}\text { Age - 16-19 years ( } 12-15 \text { years) } \\
\text { Wiek - 16-19 lat (12-15 lat) }\end{array}$ & 0.361 & 25.52 & 0.000 & & & & 0.176 & 4.276 & 0.039 \\
\hline $\begin{array}{l}\text { School year repetition: more (once) } \\
\text { Powtarzanie klasy: więcej (raz) }\end{array}$ & & & & 0.212 & 12.10 & 0.001 & & & \\
\hline \multicolumn{10}{|c|}{ Free-time activities/Spędzanie czasu wolnego } \\
\hline $\begin{array}{l}\text { Computer games every day - Yes } \\
\text { (no) } \\
\text { Gry komputerowe codziennie - Tak } \\
\text { (nie) }\end{array}$ & -0.195 & 7.38 & 0.007 & & & & & & \\
\hline $\begin{array}{l}\text { Listening music } 3 \text { h daily (less) } \\
\text { Codzienne słuchanie muzyki } \geq 3 \\
\text { godz. (mniej) }\end{array}$ & 0.149 & 4.381 & 0.036 & & & & & & \\
\hline $\begin{array}{l}\text { Organised non-sport activities - Yes } \\
\text { (no) } \\
\text { Zorganizowane zajęcia inne niż } \\
\text { sportowe - Tak (nie) }\end{array}$ & -0.228 & 11.76 & 0.001 & & & & & & \\
\hline
\end{tabular}


the frequency of drinking alcohol and getting drunk were subjective drinking norms. However, the need for stimulation most strongly determined the number of alcohol-related problems though also in this case, subjective norms remained quite a strong factor.

A large group of variables did not find their way into any of the constructed models. When controlling a number of important factors, the association of these variables with alcohol consumption proved to be too weak. This group included parental support and family conflicts, family composition and its financial status, the social climate at the centre and the length of stay in the centre, religious commitment and internalising problems. Also, out of ten analysed free-time activities, seven did not find their way to any of the models explaining drinking: spending time doing homework or surfing the internet, reading books for pleasure and hobby, shopping, participating in organised sports activities as well as individual sport activity.

\section{- Discussion}

This study showed that alcohol use, its abuse and alcohol-related problems among MOS and MOW students are determined primarily by individual and social factors. In general, these are analogous factors like those found in the general population of students attending regular schools. As in many other studies [7, 18, 3234 ], the strongest factor proved to be subjective norms about the extent to which adolescents are allowed to drink alcohol or use other psychoactive substances.

As our study, research on the individual determinants of young people's behaviour indicates the importance of sensation seeking as a significant risk factor for alcohol drinking and use of other substances. The search for strong and exciting experiences may also incline young people towards many other risk behaviours [20, 35-38].

Among the individual factors, it is also worth paying attention to the importance of self-control for the reducing of alcohol-related problems. It seems that this is a factor that can be modified in therapeutic or preventive work supporting atrisk youth in acquiring self-control skills [39]. On the other hand, a disturbing result is the link between alcohol and suicide attempts. Due to warunkującym częstość picia alkoholu i upijania się były subiektywne normy dotyczące picia. Natomiast zapotrzebowanie na stymulacje najsilniej determinowało liczbę problemów wynikających z picia alkoholu. Ale i w tym przypadku subiektywne normy pozostawały dość silnym czynnikiem.

Duża grupa zmiennych nie znalazła się w żadnym z konstruowanych modeli. Przy kontrolowaniu szeregu istotnych czynników związki tych zmiennych $\mathrm{z}$ piciem alkoholu okazały się zbyt słabe. W grupie tej znalazło się wsparcie ze strony rodziców, konflikty w rodzinie, struktura rodziny, sytuacja finansowa rodziny, klimat ośrodka, długość pobytu w ośrodku, zaangażowanie religijne i problemy internalizacyjne. Także spośród dziesięciu analizowanych czynników dotyczących spędzania wolnego czasu do żadnego $\mathrm{z}$ modeli wyjaśniających picie alkoholu nie weszło siedem zmiennych: poświęcanie czasu na odrabianie lekcji, surfowanie w internecie, czytanie książek, osobiste zainteresowania, spędzanie czasu w centrach handlowych lub sklepach, uczestniczenie w zorganizowanych zajęciach sportowych, a także uprawianie indywidualnie aktywności fizycznej.

\section{- OMÓWIENIE}

Przeprowadzone badania pokazały, że picie alkoholu, jego nadużywanie i związane z tym problemy doświadczane przez podopiecznych placówek MOS i MOW są uwarunkowane przede wszystkim czynnikami indywidualnymi i społecznymi. Zasadniczo są to analogiczne czynniki jak w przypadku ogólnej populacji uczniów uczęszczających do zwykłych szkół. Podobnie jak w wielu innych badaniach [7, 18, 32-34], najsilniejszym czynnikiem okazały się subiektywne normy dotyczące tego, na ile wolno dorastającemu pić alkohol lub sięgać po inne substancje psychoaktywne.

Tak jak w przypadku naszych badań, inne prace nad indywidualnymi determinantami zachowań młodych ludzi wskazują na istotne znaczenie poszukiwania wrażeń jako istotnego czynnika ryzyka picia alkoholu i używania innych substancji. Potrzeba silnych i ekscytujących doświadczeń może skłonić młodych ludzi do podejmowania także wielu innych ryzykownych zachowań [20, 35-38].

Spośród czynników indywidualnych warto również zwrócić uwagę na istotne znaczenie samokontroli, która sprzyja ograniczeniu problemów wynikających z picia alkoholu. Wydaje się, że jest to czynnik, który można modyfikować w pracy terapeutycznej 
the higher prevalence of this very serious problem than in the general population, the issue of providing adequate psychiatric and psychological care for MOS and MOW students should be of particular concern.

Undoubtedly, social factors also play an important role in shaping drinking patterns among young people. First of all, it is about peer influence, parenting practices and the influence of the wider social environment [19]. Peer influence is particularly important during adolescence, and numerous studies have shown that the company of young people who use psychoactive substances is a very strong risk factor [5, $9,40]$. Numerous studies have also shown that adolescents are more likely to use psychoactive substances if they believe their peers also use and accept such behaviours [21, 41-43]. The study confirmed that drinking by at-risk young people is associated with the perception of the use of psychoactive substances among close peers. What is more, the analysis showed that positive relationships with peers also increase the risk of alcohol abuse and are conducive to the occurrence of alcohol-related problems. Drinking by young people is associated with popularity, higher social group status and a greater number of friends [44-46]. Therefore it is not surprising that respondents who highly rated their peer relations also tended to drink alcohol more often.

In our study, alcohol problems among non-familial adults proved to be an important factor increasing the risk of drinking, getting drunk and experiencing alcohol-related problems. Also, studies of adolescents from the general population suggest that the impact of non-familial adults may increase the risk of adolescents' use of psychoactive substances [21, 47]. It is likely that adults set a standard of undesirable behaviours in the lives of young people, which in turn increases the risk of their use of substances [48].

The most surprising result is the lack of association between perceived parental support and getting drunk. According to resilience theory, which attempts to explain some children's surprising resilience when exposed to adversity or traumatic events, supportive relationships between parents and a child are one of the strongest predictors of positive adolescent adaptation $[49,50]$. Parental support can help build czy profilaktycznej z młodzieżą zagrożoną, ucząc ją tego typu umiejętności [39]. Niepokojącym wynikiem jest natomiast związek pomiędzy sięganiem po alkohol a próbami samobójczymi. Ze względu na większe niż w populacji generalnej rozpowszechnienie tego bardzo poważnego problemu przedmiotem szczególnej troski powinna być kwestia zapewnienia odpowiedniej opieki psychiatrycznej i psychologicznej podopiecznym MOS i MOW.

Niewątpliwie także czynniki społeczne odgrywają ważną rolę w kształtowaniu wzorców picia alkoholu wśród młodzieży. Przede wszystkim chodzi tu o wpływ rówieśników, praktyki rodzicielskie oraz wpływ szerszego otoczenia społecznego [19]. Wpływ rówieśników ma szczególne znaczenie $\mathrm{w}$ okresie dojrzewania, a liczne badania wykazały, że bardzo silnym czynnikiem ryzyka jest przebywanie w towarzystwie młodych ludzi, którzy używają substancji psychoaktywnych $[5,9,40]$. Liczne badania wykazały również, że młodzież jest bardziej skłonna do używania substancji psychoaktywnych, jeśli wierzy, że ich rówieśnicy również po nie sięgają i akceptują takie zachowania [21, 41-43]. Przeprowadzone badania potwierdziły, że picie alkoholu przez młodych ludzi z grup ryzyka jest związane z postrzeganiem używania substancji psychoaktywnych wśród bliskich kolegów. Co więcej, przeprowadzone analizy wykazały, że pozytywne relacje $\mathrm{z}$ rówieśnikami zwiększają też ryzyko nadużywania alkoholu i sprzyjają problemom wynikającym z picia alkoholu. Picie alkoholu przez młodych ludzi wiąże się z popularnością i wyższą pozycją w grupie społecznej i z większą liczbą przyjaciół [44-46], dlatego nie jest zaskakujące, że respondenci, którzy wysoko ocenili swoje relacje z rówieśnikami, również częściej piją alkohol.

W naszych badaniach ważnym czynnikiem zwiększającym ryzyko spożywania alkoholu, upijania się i doświadczania problemów związanych z alkoholem okazały się problemy alkoholowe wśród znajomych dorosłych spoza rodziny. Także badania młodzieży z populacji ogólnej sugerują, że wpływ dorosłych niebędących rodzicami może zwiększać ryzyko używania substancji psychoaktywnych przez młodzież $[21,47]$. Wskazuje to, że również ci dorośli modelują niepożądane zachowania w życiu młodych ludzi, co z kolei zwiększa ryzyko używania substancji przez młodzież [48].

Najbardziej zaskakującym wynikiem jest brak związku między postrzeganym wsparciem rodzicielskim a upijaniem się przez badanych. Zgodnie $\mathrm{z}$ teorią resilience, próbującą wyjaśnić fenomen zaskakującej odporności części dzieci narażonych na przeciwności losu czy zdarzenia traumatyczne, 
a young person's resilience to negative social influences [13]. The positive impact of parental support on young people's risk behaviour has been demonstrated in many studies also conducted in Poland. For example, a study in Warsaw among junior high school students revealed that maternal support was associated with a reduced risk of alcohol consumption [21]. Data collected in the presented study indicate that in the case of respondents from special education centres, parental support is not a significant factor in alcohol use. This is probably due to that alcohol consumption and related problems are more common in families of MOS and MOW pupils than among others at regular schools. Parental support may therefore not rule out a child's approval of drinking. However, the result does not mean that the family environment is irrelevant in special education youth drinking. On the contrary, the importance of the family environment was confirmed by another important protective factor identified in our study, which was parental monitoring over how young people spend their free time.

\section{- CONCLUSIONS}

Preventive actions involving young people in special education centres should be focused on factors that may be modified like shaping subjective norms against drinking and alcohol abuse, developing self-control, offering young people organised leisure activities tailored to their needs, suicide prevention and strengthening pupils' mental health. relacje wspierające między rodzicami a dzieckiem są jednym $\mathrm{z}$ najsilniejszych predyktorów pozytywnej adaptacji młodzieży $[49,50]$. Wsparcie rodzicielskie może pomóc $\mathrm{w}$ budowaniu odporności młodzieży na negatywne wpływy społeczne [13]. Pozytywny wpływ wsparcia rodzicielskiego na ograniczenie zachowań ryzykownych został udowodniony $\mathrm{w}$ wielu badaniach, również przeprowadzonych w Polsce. Dla przykładu: badanie przeprowadzone $\mathrm{w}$ Warszawie wśród uczniów gimnazjum wykazało, że wsparcie ze strony matki wiązało się ze zmniejszeniem ryzyka sięgania po alkohol [21]. Dane zebrane w prezentowanym badaniu wskazują, że w przypadku respondentów z placówek edukacji specjalnej wsparcie ze strony rodziców nie jest znaczącym czynnikiem przeciwdziałającym używaniu alkoholu. Prawdopodobnie jest to spowodowane faktem, że spożywanie alkoholu i związane z nim problemy występują częściej w rodzinach podopiecznych MOS i MOW niż wśród uczniów szkół ogólnodostępnych. Zapewnienie wsparcia rodzicielskiego może zatem nie wykluczać aprobaty dla picia alkoholu przez dziecko. Taki wynik nie oznacza, że środowisko rodzinne nie ma w ogóle znaczenia dla picia alkoholu przez młodzież objętą specjalną edukacją. Przeciwnie, znaczenie środowiska rodzinnego potwierdził zidentyfikowany w naszych badaniach inny istotny czynnik chroniący - monitorowanie przez rodziców, w jaki sposób ich dziecko spędza wolny czas.

\section{WNIOSKI}

Działania profilaktyczne obejmujące młodzież z ośrodków specjalnych powinny być ukierunkowane na możliwe do modyfikacji czynniki: kształtowanie subiektywnych norm przeciwnych piciu i nadużywaniu alkoholu, rozwijanie umiejętności samokontroli, oferowanie młodzieży dopasowanych do ich potrzeb zorganizowanych zajęć w czasie wolnym, zapobieganie próbom samobójczym i wzmacnianie zdrowia psychicznego podopiecznych.

\section{Conflict of interest/Konflikt interesów}

None declared./Nie występuje.

Financial support/Finansowanie

The article was prepared within the frame of the research project financed by the National Health Program for 2016-2020. 
Artykuł został przygotowany w ramach projektu badawczego finansowanego ze środków Narodowego Programu Zdrowia na lata 2016-2020.

\section{Ethics/Etyka}

The project "Supporting research in the area of risk and protective factors associated with alcohol-use related problems" was approved by the Bioethics Committee of the Institute of Psychiatry and Neurology in Warsaw, Resolution No. 342017 of 26 October 2017.

Projekt „Wspieranie badań naukowych w obszarze czynników ryzyka i czynników chroniących przed problemami wynikającymi z picia alkoholu" uzyskał zgodę Komisji Bioetycznej Instytutu Psychiatrii i Neurologii w Warszawie, Uchwała nr 342017 z dnia 26 października $2017 \mathrm{r}$.

The work described in this article has been carried out in accordance with the Code of Ethics of the World Medical Association (Declaration of Helsinki) on medical research involving human subjects, Uniform Requirements for manuscripts submitted to biomedical journals and the ethical principles defined in the Farmington Consensus of 1997.

Treści przedstawione w pracy są zgodne z zasadami Deklaracji Helsińskiej odnoszącymi się do badań z udziałem ludzi, ujednoliconymi wymaganiami dla czasopism biomedycznych oraz z zasadami etycznymi określonymi w Porozumieniu z Farmington w 1997 r.

\section{References/Piśmiennictwo}

1. Degenhardt L, Stockings E, Patton G, Hall WD, Lynskey M. The increasing global health priority of substance use in young people. Lancet Psychiatry 2016; 3(3): 251-64. DOI: 10.1016/S2215-0366(15)00508-8.

2. Wójtowicz S. Picie alkoholu przez dorastających w kontekście realizacji zadań rozwojowych. Alkoholizm i Narkomania 1996; 22(1): 75-82. http://ain.ipin.edu.pl/archiwum/1996/1/AiN_1-1996-08.pdf [Access: 24.09.2019].

3. Zucker R, Boyd G, Howard J (eds.). Powstawanie problemów alkoholowych. Biologiczne, psychospoleczne i socjologiczne czynniki ryzyka uzależienia od alkoholu. Warszawa: Państwowa Agencja Rozwiązywania Problemów Alkoholowych; 1997.

4. U.S. Department of Health and Human Services, Public Health Service, National Institute on Alcohol Abuse and Alcoholism. VIII Raport Specjalny dla Kongresu USA. Alkohol i zdrowie. Warszawa: Państwowa Agencja Rozwiązywania Problemów Alkoholowych; 1995.

5. Dielman T, Butchart A, Shope J, Miller M. Environmental correlates of adolescent substance use and misuse: implications for prevention programs. Int J Addict 1991; 25(7A \& 8A): 855-80. https://doi.org/10.3109/10826089109071027.

6. Dielman TE, Butchart AT, Shope JT. Structural equation model tests of patterns of family interactions, peer alcohol use and interpersonal predictors of adolescent alcohol use and misuse. J Drug Educ 1993; 23(3): 273-316. DOI: 10.2190/8YXM-K9GB-B8FD-82NQ.

7. Hansen WB, Rose LA, Dryfoos JG. Causal factors, interventions, and policy considerations in school-based substance abuse prevention. Washington, DC: Report to the Office of Technology Assessment; 1993.

8. Hawkins DJ, Catalano RF, Miller JY. Risk and protective factors for alcohol and other drug problems in adolescence and early adulthood: Implications for substance abuse prevention. Psychol Bull 1992; 112(1): 64-105.

9. Jessor R. Problem-Behavior Theory, Psychosocial Development, and Adolescent Problem Drinking. Br J Addict 1987; 82(4): 331-42. https://doi.org/10.1111/j.1360-0443.1987. tb01490.

10. Jessor R, Van Den Bos J, Vanderryn J, Costa F, Turbin M. Protective factors in adolescent problem behavior: moderator effects and developmental change. Dev Psychol 1995; 31(6): 923-33. https://ibs.colorado.edu/jessor/pubs/1995_Jessor_VanDenBos_Vanderryn_etal_DEVPSYCH_ProblemBehaviorModeratorEffects.pdf [Access: 24.09. 2019]. 
11. Johnston LD, O'Malley PM, Bachman JG. National survey results on drug use from the Monitoring the Future study, 1975-1992. Volume I: Secondary school students. Rockville, MD: National Institute on Drug Abuse; 1993.

12. Scheier L, Botvin G, Baker E. Risk and protective factors as predictors of adolescent alcohol involvement and transitions in alcohol use: a prospective analysis. $J$ Stud Alcohol 1997; 58(6): 652-67. http://wordpress.larsri.org/wp-content/uploads/1997-Scheier-et-alJSA.pdf [Access: 24.09.2019].

13. Wills T, Vaccaro D, McNamara G. The role of life events, family support, and competence in adolescent substance use: a test of vulnerability and protective factors. $\mathrm{Am}$ JCommunity Psychol 1992; 20(3): 349-74. https://link.springer.com/content/pdf/10.1007/ BF00937914.pdf [Access: 24.09.2019].

14. Windle M, Miller-Tutzauer C, Domenico D. Alcohol use, suicidal behavior, and risky activities among adolescents. $J$ Res Adolesc 1992; 2(4): 317-30. DOI: $10.1207 /$ s15327795jra0204_2.

15. Bobrowski K. Czas wolny a zachowania ryzykowne młodzieży. Alkoholizm i Narkomania 2007; 20(3): 267-87. http://www.fpn.ipin.edu.pl/archiwum/1-3/t20n3_2.pdf [Access: 24.09.2019].

16. Okulicz-Kozaryn K, Pisarska A. Poczucie własnej skuteczności a używanie substancji psychoaktywnych przez młodzież. Badania pilotażowe. Alkoholizm i Narkomania 2001; 14(4): 565-77. http://ain.ipin.edu.pl/archiwum/2001/4/AiN_4-2001-11.pdf [Access: 24.09.2019].

17. Okulicz-Kozaryn K, Borucka A. Wzory picia napojów alkoholowych. In: Ostaszewski K (ed.). Monitorowanie zachowań ryzykownych, zachowań nałogowych, problemów zdrowia psychicznego 15-letniej młodzieży. Badania mokotowskie 2004-2016. Badania ukraińskie, obwód lwowski 2016. Warszawa: Instytut Psychiatrii i Neurologii; 2017, p. 77-96. http://www.ipin.edu.pl/wp-content/uploads/2019/06/Badanie_mokotowskie_2017_odd.pdf [Access: 24.09.2019].

18. Ostaszewski K, Bobrowski K, Borucka A, Pisarska A. Subiektywne normy a intencja używania substancji psychoaktywnych przez nastolatków. Alkoholizm i Narkomania 2002; 15(3): 305-25. http://ain.ipin.edu.pl/archiwum/2002/3/AiN_3-2002-07.pdf [Access: 24 .09.2019].

19. Ostaszewski K. Problemy nastolatków związane z używaniem substancji psychoaktywnych. Alkoholizm i Narkomania 2008; 21(4): 363-89. http://ain.ipin.edu.pl/archiwum/2008/4/t21n4_2.pdf [Access: 24.09.2019].

20. Ostaszewski K, Rustecka-Krawczyk A, Wójcik M. Czynniki chroniące i czynniki ryzyka zwiazane z zachowaniami problemowymi warszawskich gimnazjalistów: klasy I-III. Warszawa: Instytut Psychiatrii i Neurologii; 2011. http://www.ipin.edu.pl/wp-content/ uploads/2019/06/Raport. IPiN_2011_v10PRESS.pdf [Access: 24.09.2019].

21. Pisarska A, Eisman A, Ostaszewski K, Zimmerman MA. Alcohol and cigarette use among Warsaw adolescents: factors associated with risk and resilience. Subst Use Misuse 2016; 51(10): 1283-96. DOI: 10.3109/10826084.2016.1168442.

22. Stępień E. Ocena własnych relacji z rodziną a picie alkoholu przez dorastających. Alkoholizm i Narkomania 1996; 9(1): 83-96. http://ainspin.edu.pl/archiwum/1996/1/AiN_11996-09.pdf [Access: 24.09.2019].

23. Wójtowicz S. Relacje z rówieśnikami a picie alkoholu przez dorastających. Alkoholizm $i$ Narkomania 1993; 6(2): 89-101. http://ainspin.edu.pl/archiwum/1993/14/AiN_141993_08.pdf [Access: 24.09.2019].

24. Śliwa S. Wybrane problemy resocjalizacji nieletnich w mlodzieżowych ośrodkach wychowawczych. Seria: Monografie i opracowania, Wydawnictwa Wyższej Szkoły Zarządzania i Administracji w Opolu. Opole: Wydawnictwo Instytut Śląski; 2013. https://depot.ceon. pl/bitstream/handle/123456789/3449/\%C5\%9Aliwa\%20Wybrane\%20problemy\%20resocjalizacji.pdf [Access: 24.09.2019].

25. Kepper A, Dorsselaer S, Monshouwer K, Vollebergh W. Substance use by adolescents in special education and residential youth care institution. Eur Child Adolesc Psychiatry 2011; 20: 311-9. DOI: 10.1007/s00787-011-0176-2. 
26. ESPAD Group. ESPAD Report 2015: Results from the European School Survey Project on Alcohol and Other Drugs. Luxembourg: Publications Office of the European Union; 2016. http://www.espad.org/sites/espad.org/files/ESPAD_report_2015.pdf [Access: 24.09.2019].

27. Miech RA, Johnston LD, O’Malley PM, Bachman JG, Schulenberg JE, Patrick ME. Monitoring the Future national survey results on drug use, 1975-2016: Volume I, Secondary school students. Ann Arbor: Institute for social research, the University of Michigan; 2017. https://files.eric.ed.gov/fulltext/ED578534.pdf [Access: 24.09.2019].

28. Pennay A, Livingston M, MacLean S. Young people are drinking less: It is time to find out why. Drug Alcohol Rev 2015; 34(2): 115-8. DOI: 10.1111/dar.12255.

29. Greń J, Bobrowski KJ, Ostaszewski K, Pisarska A. Prevalence of psychoactive substance use among students attending youth correctional centres. Alcohol Drug Addict 2019; 32(4): 267-90.

30. Henderson M, Nixon C, McKee MJ, Smith D, Wight D, Elliott L. Poly-substance use and sexual risk behaviours: a cross-sectional comparison of adolescents in mainstream and alternative education settings. BMC Public Health 2019; 19: 564. https://doi.org/10.1186/ s12889-019-6892-0.

31. Pisarska A, Bobrowski KJ, Greń J, Ostaszewski K. Risk and protective factors associated with alcohol and other substance use among students attending youth correctional centres: study design and methodology. Alcohol Drug Addict 2019; 32(4): 247-66.

32. Bogart LM, Collins RL, Ellickson PL, Klein DJ. Adolescent predictors of generalized health risk in young adulthood: a 10-year longitudinal assessment. J Drug Issues 2006; 36(3): 571-96. DOI: 32. 10.1177\%2F002204260603600304.

33. Griffin KW, Botvin GJ, Scheier LM, Doyle MM, Williams C. Common predictors of cigarette smoking, alcohol use, aggression, and delinquency among inner-city minority youth. Addict Behav 2003; 28(6): 1141-8. DOI: 10.1016/S0306-4603(02)00225-3.

34. Hair EC, Park MJ, Ling TJ, Moore KA. Risky behaviors in late adolescence: co-occurrence, predictors, and consequences. $J$ Adolesc Health 2009; 45(3): 253-61. DOI: 10.1016/j.jadohealth.2009.02.009.

35. Kelley AE, Schochet T, Landry CF. Risk taking and novelty seeking in adolescence: introduction to part 1. Ann N Y Acad Sci 2004; 1021: 27-32. DOI: 10.1196/annals.1308.003

36. Steinberg L. Risk taking in adolescence: what changes and why? Ann N Y Acad Sci 2004; 1021: 51-8. DOI: 10.1196/annals.1308.005.

37. Steinberg L. Risk taking in adolescence. New perspectives from brain and behavioral science. Current Directions in Psychological Science 2007; 16(2): 55-9. http://www.jstor. org/stable/20183162 [Access: 24.09.2019].

38. Zuckerman M. Behavioral expressions and biosocial bases of sensation seeking. New York: Cambridge Press; 1994.

39. Glassman T, Werch CC, Jobli E. Alcohol self-control behaviors of adolescents. Addict Behav 2007; 32(3): 590-7. DOI: 10.1016/j.addbeh.2006.06.003.

40. Kandel DB, Andrews K. Processes of adolescent socialization by parents and peers. Int J Addict 1987; 22(4): 319-42. DOI: 10.3109/10826088709027433.

41. Berkowitz AD. The social norms approach: theory, research and annotated bibliography. 2004. http://www.alanberkowitz.com/articles/social_norms.pdf [Access: 24.09.2019].

42. Borsari B, Carey KB. Peer influences on college drinking: a review of the research. J Subst Abuse 2001; 13(4): 391-424.

43. Borsari B, Carey KB. Descriptive and injunctive norms in college drinking: a meta-analytic integration. J Stud Alcohol 2003; 64 (3): 331-41. DOI: 10.15288/jsa.2003.64.331.

44. Hoel S, Eriksen B, Breidablik HJ, Meland E. Adolescent alcohol use, psychological health and social integration. Scand J Pub Health 2004; 32(5): 361-7. DOI: 10.1080/14034940410027894.

45. Demant J, Jarvinen M. Constructing maturity through alcohol experience - Focus group interviews with teenagers. Addict Res Theory 2006; 14(6): 589-602. https://doi.org/ $10.1080 / 16066350600691683$. 
46. Pedersen W, Kolstad A. Adolescent alcohol abstainers: traditional patterns in new groups. Acta Sociol 2000; 43(3): 219-33. http://dx.doi.org/10.1177/000169930004300303.

47. Hurd NM, Zimmerman MA. Natural mentors, mental health, and risk behaviors: a longitudinal analysis of African American adolescents transitioning into adulthood. $\mathrm{Am}$ J Community Psychol 2010; 46(1-2): 36-48. DOI:10.1007/s10464-010-9325-x.

48. Parry CDH, Morojele NK, Saban A, Flisher A. Brief report: Social and neighbourhood correlates of adolescent drunkenness: A pilot study in Cape Town, South Africa. J Adolesc 2004; 27(3): 369-74. DOI: 10.1016/j.adolescence.2003.09.005.

49. Fergus S, Zimmerman MA. Adolescent resilience: A framework for understanding healthy development in the face of risk. Ann Rev Pub Health 2005; 26: 399-419. https:// doi.org/10.1146/annurev.publhealth.26.021304.144357.

50. Luthar S. Resilience in development: A synthesis of research across five decades. In: Cicchetti D, Cohen D (eds.). Developmenthal Psychopatology: Risk, disorder, and adaptation. Vol. 3 ( $2^{\text {nd }}$ ed.). New York: Wiley; 2006, p. 740-95. 
